\section{Hemodynamic variables in piglets anesthetized with isoflurane or propofol, kept under spontaneous ventilation and $\mathrm{FIO}_{2}$ of 0.5}

[Variáveis hemodinâmicas em suínos anestesiados com isoflurano ou propofol, mantidos sob ventilação espontânea e FIO2 de 0,5]

\begin{abstract}
This study aimed to evaluate comparatively the effects of propofol or isoflurane on hemodynamic variables in piglets that received inspired oxygen fraction $\left(\mathrm{FIO}_{2}\right)$ of 0.5 under spontaneous ventilation. Therefore, sixteen piglets weighing $16 \pm 1.1 \mathrm{~kg}$, were randomly divided into two groups: GI (Isoflurane and $\mathrm{FIO}_{2}$ of 0.5 ) and GP (Propofol and $\mathrm{FIO}_{2}$ of 0.5). Heart rate (HR), systolic, diastolic and mean arterial pressure (SAP, DAP and MAP), central venous pressure (CVP), cardiac output (CO), mean pulmonary arterial pressure (mPAP) and mean capillary pulmonary pressure (mCPP) were assessed 40 minutes after anesthetic induction (T0), followed by 15 minutes intervals (from T15 to T60). The variables cardiac index (CI), stroke volume (SV), stroke index (SI), total peripheral resistance (TPR), total peripheral resistance index (TPRI), pulmonary vascular resistance (PVR), and pulmonary vascular resistance index (PVRI) were calculated. SAP and TPRI were significantly different between groups at T30 and T60 $(\mathrm{P}<0.05)$ with higher GP values being recorded. There were no differences in the other variables, however, GP presented mean closer to normality on most of the analyzed variables. Therefore, we conclude that total intravenous anesthesia with propofol presented greater stability of the hemodynamic variables evaluated.
\end{abstract}

Keywords: pigs, inhalation, intravenous, oxygen, cardiovascular

\title{
RESUMO
}

O objetivo deste estudo foi avaliar comparativamente os efeitos do propofol ou do isoflurano sobre as variáveis hemodinâmicas em leitões que receberam fração inspirada de oxigênio (FIO2) de 0,5 sob ventilação espontânea. Dezesseis leitões, pesando $16 \pm 1,1 \mathrm{~kg}$, foram divididos aleatoriamente em dois grupos: GI (isoflurano e FIO2 de 0,5) e GP (propofol e FIO2 de 0,5). A frequência cardíaca (FC), a pressão arterial sistólica, a diastólica e a média (PAS, PAD e PAM), a pressão venosa central (PVC), o débito cardíaco $(D C), a$ pressão média da artéria pulmonar (PAPm) e a pressão média capilar pulmonar (PCPm) foram avaliados 40 minutos após a indução anestésica (T0), seguida por intervalos de 15 minutos (de T15 a T60). As variáveis índice cardíaco (IC), volume sistólico (VS), índice sistólico (SI), resistência periférica total (RPT), índice de resistência periférica total (IRPT), resistência vascular pulmonar (RVP) e índice de resistência vascular pulmonar (IRVP) foram calculadas. PAS e IRPT foram significativamente diferentes entre os grupos em T30 e T60 $(P<0,05)$ com maiores valores de GP sendo registrados. Não houve diferenças nas demais variáveis, entretanto o GP apresentou médias próximas da normalidade na maioria das variáveis analisadas. Portanto, concluiu-se que a anestesia intravenosa total com propofol apresentou maior estabilidade das variáveis hemodinâmicas avaliadas.

Palavras-chave: porcos, anestesia inalatória, anestesia intravenosa, oxigênio, cardiovascular

Recebido em 25 de maio de 2018

Aceito em 30 de abril de 2019

E-mail: cleber.ido@hotmail.com 


\section{INTRODUCTION}

The anesthesiologist should always try to establish the best anesthetic protocol for the patient. Currently, several anesthetic drugs with different pharmacodynamic and pharmacokinetic characteristics are available, as well as several techniques, such as total intravenous anesthesia (TIVA) and general inhalation anesthesia. Such techniques are largely used in both human and veterinary medicine. The isoflurane (1-chloro2,2,2-trifluoroethyl difluoromethyl ether) is a halogenated, enflurane isomer, which has a low blood:gas solubility coefficient (1.46), providing a rapid induction and recovery from anesthesia (Steffey and Mama, 2007). Like other anesthetics, isoflurane can cause dose-dependent cardiovascular changes (Egger II, 1981). Increased heart rate (HR) may be observed as a compensatory response to decreased cardiac output (Pagel et al., 1991). According to Egger II (1981), there is the stimulation of betaadrenergic receptors, reducing peripheral vascular resistance and consequently hypotension is observed.

Propofol (2.6-diisopropylphenol) is a general non-barbiturate anesthetic administered exclusively intravenously (IV) (Glowaski and Wetmore, 1999). It is currently considered the most recommended hypnotic drug for TIVA because of its low cumulative effect (Musk et al., 2005) and it is highly lipophilic nature, which ensures rapid redistribution between brain and tissues (Shafer 1993; Glowaski and Wetmore, 1999). It allows a fast and smooth recovery after continuous infusion (Aguiar et al., 2001). In the cardiovascular system, a decrease in blood pressure due to arterial and venous vasodilation (Goodchild and Serrao, 1989) with a $20 \%$ to $40 \%$ decrease in blood pressure can be observed, while HR remains stable (Brussel et al., 1989; Shafer, 1993). Whitwam et al. (2000) observed a reduction in blood pressure proportional to the increase in the plasma concentration of propofol. However, some authors report that both bradycardia and tachycardia can be observed (Massone and Cortopassi, 2007). Aguiar et al. (2001), report an increase in HR after 20 minutes of anesthetic induction, being correlated with a decrease in blood pressure.

Monitoring the hemodynamic variables is crucial to ensure adequate oxygenation and tissue perfusion and it is useful to prevent severe alterations, allowing its prompt identification and treatment (Pinsky and Payen, 2005). The aim of this study was to compare the hemodynamic effects of propofol TIVA with isoflurane anesthesia in piglets spontaneously breathing an inspired oxygen fraction $\left(\mathrm{FIO}_{2}\right)$ of 0.5 . Our hypothesis was that isoflurane kept all hemodynamic variables stable, without presenting significant changes during the evaluation period.

\section{MATERIAL AND METHODS}

The research project was approved by the Ethics and Animal Welfare Commission of the FCAV/UNESP, protocol no. 6,315-16, according to the National Ethical Principles of Animal Experimentation. A total of 16 male and female Large White pigs, approximately 7 weeks of age and weighing $15-17 \mathrm{~kg}$, were studied. The animals were kept in individual stalls where they were fed and watered without restrictions along the 7 days before trial for adaptation and acclimatization. Complete physical examination and thoracic radiographs were performed to rule out pulmonary pathologies. Only healthy animals were used in the experiment.

The piglets were submitted to a 12 hour food fasting and water fasting of 2 hours, prior to the study. Preanesthetic medication was azaperone (2mg/Kg; Destress®, DES-VET, São Paulo, Brazil) by intramuscular (IM) injection into caudal portion of biceps femoris muscle. Twenty minutes passed for the initiation of sedation, followed by catheterization of the auricular vein for administration of drugs. Anesthetic induction was performed with propofol IV (Propovan ${ }^{\circledR}$, Cristália, Brazil) in all piglets, at the dose needed for the animals to lose their laryngeal and tracheal reflexes $(10.54 \pm 1.15 \mathrm{mg} / \mathrm{Kg})$, and they were then intubated with an orotracheal tube of diameter adequate to the size of each animal, which was linked to the inhalation anesthesia device (SAT 500 - K. Takaoka Ind. E Com Ltda., Brazil) with an anesthetic circuit with partial gas rebreathing for the supply of gas, in the proportion of 50:50 oxygen:compressed air. Readings for $\mathrm{O}_{2}$ concentration were verified on a multiparameter monitor (Dixtal DX-2020D-C Dixtal Biomédica Ind. Com. Ltda., Brazil), in which the gas analyzer sensor was adapted to the proximal end of the tube following orotracheal 
intubation. The piglets were then positioned in the right lateral decubitus, on an active thermal mattress (Gaymar - mod. TP - 500 - England).

The piglets were randomly divided into 2 groups of eight animals each, called GI and GP, which differed by the use of maintenance anesthetics. At GP, continuous infusion of propofol was administered initially at the rate of $0.5 \mathrm{mg} / \mathrm{Kg} / \mathrm{min}$ IV using an infusion pump (ST 1000 Plus Syringe Pump, Samtronic ${ }^{\circledR}$, Brazil), and GI initially received $1.5 \mathrm{~V} \%$ of isoflurane (Isoflurane ${ }^{\circledR}, \quad$ Cristália, Brazil) through a calibrated vaporizer (Penlon Pfill - Selectatec Model). To measure the bispectral index (BIS), the tricotomy of the head area, comprised between the frontal and zygomatic regions, was performed. Then the area was cleaned with ether and antisepsis was done using 70\% alcohol in order to improve the signal quality. Subsequently, BIS monitor electrodes were positioned (Biespectral Index Monitor Systems Mod XP, Inc., USA), with the primary on the midline, located at a third of the distance between an imaginary line connecting the left and right zygomatic processes and the most distal palpable part of the sagittal crest. The tertiary electrode was placed in rostral position to the tragus of the right ear and the secondary and quaternary electrodes on the temporal bone, on the midline comprised between the two firsts. The monitoring techniques, as well the value validation variables were adapted for piglets as described by Guerrero and Nunes (2003) for dogs. The GP animals maintained the BIS values from 55 to 65 . In the GI, in order to obtain anesthetic equipotency, the isoflurane concentration was adjusted in a way to maintain this bispectral index range.

Then, a right femoral artery catheterization was performed. The catheter was connected to the invasive arterial pressure channel of the multiparametric monitor (Dixtal DX-2020D-C Dixtal Biomédica Ind. Com. Ltda., Brazil), which transducer was positioned at the heart level as "zero reference" for calibration. Then, cervical region antisepsis was performed with chlorhexidine and alcohol to perform an incision in the skin, enough to expose the left jugular vein which was identified after blunt dissection of the subcutaneous tissue. After this, the vessel was isolated with a nylon thread (3-0 Nylon, Shalon suturas ${ }^{\circledR}$, Brazil) and after perforating it with a
18 gauge hypodermic needle, the Swan-Ganz catheter (Swan-Ganz Pediatric Catheter, mod. 132-5F, Edwards Lifesciences LLC, USA) was introduced into its lumen and positioned in the pulmonary artery by the observation of pressure waves, according to a technique described by Swan-Ganz and cited by Santos et al. (2011). The following variables were evaluated through a multiparameter monitor: heart rate (HR), systolic arterial pressure (SAP), diastolic arterial pressure (DAP), mean arterial pressure (MAP), central venous pressure (CVP), cardiac output (CO), mean pulmonary arterial pressure (mPAP) and mean capillary pulmonary pressure (mCPP).

From these data, the following variables were obtained by mathematical calculations as described by Nunes (2010): CI = $\mathrm{CO} / \mathrm{BSA}$, where $\mathrm{CI}=$ cardiac index, $\mathrm{CO}=$ cardiac output, BSA = body surface area $\left(\mathrm{m}^{2}\right)$, which was estimated according to the weight of the animals, according to Ogilvie (1996); SV = $\mathrm{CO} / \mathrm{HR}$, where $\mathrm{SV}=$ stroke volume, $\mathrm{CO}=$ cardiac output, $\mathrm{HR}=$ heart rate; $\mathrm{SI}=\mathrm{SV} / \mathrm{BSA}$, Where $\mathrm{SI}=$ stroke index, $\mathrm{SV}=$ stroke volume, BSA = body surface area $\left(\mathrm{m}^{2}\right)$; TPR = $(\mathrm{MAP} / \mathrm{CO}) \times 79.9$, where $\mathrm{TPR}=$ total peripheral resistance, $\mathrm{MAP}=$ mean arterial pressure, $\mathrm{CO}=$ cardiac output, $79.9=$ correction factor $(\mathrm{mmHg} \mathrm{x}$ min $\mathrm{L}^{-1}$ dyne $\mathrm{x}$ sec $\mathrm{cm}^{5-1}$ ); TPRI $=$ TPR/BSA where TPRI $=$ total peripheral resistance index, $\mathrm{TPR}=$ total peripheral resistance, $\mathrm{BSA}=$ body surface area $\left(\mathrm{m}^{2}\right) ;$ PVR $=[(\mathrm{mPAP}-\mathrm{mCPP}) /$ $\mathrm{CO}] \mathrm{x} 79.9$, where PVR = pulmonary vascular resistance, $\mathrm{mPAP}=$ mean pulmonary arterial pressure, $\mathrm{mCPP}=$ mean capillary pulmonary pressure, $\mathrm{CO}=$ cardiac output, $79.9=$ correction factor $\left(\mathrm{mmHg} \times \min \mathrm{L}^{-1}\right.$ dyne $\mathrm{x}$ sec $\mathrm{cm}^{-1}$ ); PVRI = PVR/BSA, where PVRI = pulmonary vascular resistance index, $\mathrm{PVR}=$ pulmonary vascular resistance, $\mathrm{BSA}=$ body surface area $\left(\mathrm{m}^{2}\right)$.

The evaluation of the variables started 40 minutes after induction of anesthesia (T0), followed by new measurements at 15 minute intervals (T15, T30, T45 and T60), completing a total of five evaluations. After collecting the variables, anesthetic ministration was stopped and penicillin $G$ benzathine (Penfort ${ }^{\circledR}$ PPU, Ourofino Agronegócio, Brazil) was provided in a single dose of $20.000 \mathrm{IU} / \mathrm{Kg} \mathrm{IM}$, sodium dipyrone (D-500® - Dipirona sódica 500mg, Fort Dodge, Brazil) 50mg/Kg IM twice daily for 3 days, and 
meloxicam (Maxicam ${ }^{\circledR} \quad 2 \%, \quad$ Ourofino Agronegócio, Brazil) $0.4 \mathrm{mg} / \mathrm{Kg}$ IM at the first day and $0.2 \mathrm{mg} / \mathrm{Kg}$ at the second and third days. Daily local dressings with $1 \%$ chlorhexidine were also performed for 7 days.

For the analysis of the studied variables, the design used was the subdivided plots, testing the group factor ( 2 levels) in the plots and the time factor (5 levels) in the subplots, with eight replications per group. Tukey test was used for the multiple comparisons of the means (significance level $=0.05$ ). For these analyzes, General Linear Models (GLM) procedure of SAS software (SAS 9.1, SAS Institute, NC, USA) was used.

\section{RESULTS}

All animals recovered from anesthesia without any complications. There was no statistical difference between groups and between periods of time in the same groups for HR, DAP, MAP, CPV, CI, SV, SI, mPAP, mCPP, TRP, PVR, TPRI. For SAP, the means presented statistical differences between groups at T30 and T60. Regarding the TPRI, they also showed significant differences between groups at T30 and T60 (Table 1).

Table 1. Hemodynamic variables in piglets $(n=16)$, anesthetized with isoflurane $(\mathrm{GI}, \mathrm{n}=8)$ or propofol $(\mathrm{GP}, \mathrm{n}=8)$, kept under spontaneous ventilation and submitted to the inspired fraction of oxygen $\left(\mathrm{FIO}_{2}\right)$ of 0.5 - Jaboticabal, SP - 2016

\begin{tabular}{|c|c|c|c|c|c|c|}
\hline \multirow{2}{*}{ Variables } & \multirow[b]{2}{*}{ Groups } & \multicolumn{5}{|l|}{ Timing } \\
\hline & & T0 & $\mathrm{T} 15$ & $\mathrm{~T} 30$ & $\mathrm{~T} 45$ & T60 \\
\hline \multirow[t]{2}{*}{ HR (bpm) } & GI & $110 \pm 15$ & $114 \pm 30$ & $118 \pm 30$ & $117 \pm 26$ & $125 \pm 36$ \\
\hline & GP & $123 \pm 15$ & $128 \pm 19$ & $127 \pm 27$ & $133 \pm 26$ & $135 \pm 25$ \\
\hline \multirow[t]{2}{*}{ SAP (mmHg) } & GI & $88 \pm 13$ & $88 \pm 13$ & $83 \pm 8^{\mathrm{A}}$ & $84 \pm 11$ & $83 \pm 9^{\mathrm{A}}$ \\
\hline & GP & $97 \pm 12$ & $95 \pm 8$ & $98 \pm 15^{\mathrm{B}}$ & $94 \pm 17$ & $97 \pm 16^{\mathrm{B}}$ \\
\hline \multirow[t]{2}{*}{ DAP (mmHg) } & GI & $59 \pm 16$ & $53 \pm 7$ & $57 \pm 8$ & $57 \pm 8$ & $53 \pm 9$ \\
\hline & GP & $60 \pm 8$ & $65 \pm 17$ & $58 \pm 12$ & $60 \pm 13$ & $62 \pm 11$ \\
\hline \multirow[t]{2}{*}{ MAP (mmHg) } & GI & $71 \pm 10$ & $68 \pm 9$ & $70 \pm 6$ & $69 \pm 8$ & $68 \pm 8$ \\
\hline & GP & $73 \pm 11$ & $74 \pm 15$ & $76 \pm 13$ & $75 \pm 14$ & $77 \pm 13$ \\
\hline \multirow[t]{2}{*}{$\mathrm{CPV}(\mathrm{mmHg})$} & GI & $8 \pm 1$ & $5 \pm 2$ & $5 \pm 2$ & $6 \pm 2$ & $7 \pm 2$ \\
\hline & GP & $6 \pm 6$ & $5 \pm 3$ & $7 \pm 4$ & $9 \pm 5$ & $9 \pm 5$ \\
\hline \multirow{2}{*}{$\mathrm{CO}(\mathrm{L} / \mathrm{min})$} & GI & $3.54 \pm 0.46$ & $3.94 \pm 0.89$ & $3.88 \pm 0.76$ & $3.73 \pm 0.72$ & $3.63 \pm 0.83$ \\
\hline & GP & $3.48 \pm 0.94$ & $3.77 \pm 1.15$ & $3.61 \pm 1.14$ & $3.73 \pm 1.02$ & $3.50 \pm 1.00$ \\
\hline \multirow{2}{*}{$\mathrm{CI}\left(\mathrm{L} / \mathrm{min} \times \mathrm{m}^{2}\right)$} & GI & $5.29 \pm 0.68$ & $5.89 \pm 1.33$ & $5.78 \pm 1.06$ & $5.57 \pm 1.02$ & $5.41 \pm 1.22$ \\
\hline & GP & $5.56 \pm 1.43$ & $6.02 \pm 1.78$ & $5.78 \pm 1.81$ & $5.97 \pm 1.62$ & $5.59 \pm 1.57$ \\
\hline \multirow[t]{2}{*}{$\mathrm{SV}(\mathrm{mL} / \mathrm{bpm})$} & GI & $0.03 \pm 0.01$ & $0.04 \pm 0.01$ & $0.03 \pm 0.01$ & $0.03 \pm 0.01$ & $0.03 \pm 0.01$ \\
\hline & GP & $0.03 \pm 0.01$ & $0.03 \pm 0.01$ & $0.03 \pm 0.01$ & $0.03 \pm 0.01$ & $0.03 \pm 0.01$ \\
\hline \multirow[t]{2}{*}{$\mathrm{SI}\left(\mathrm{mL} / \mathrm{bpm} \times \mathrm{m}^{2}\right)$} & GI & $0.05 \pm 0.01$ & $0.05 \pm 0.01$ & $0.05 \pm 0.01$ & $0.05 \pm 0.01$ & $0.04 \pm 0.01$ \\
\hline & GP & $0.05 \pm 0.01$ & $0.05 \pm 0.01$ & $0.05 \pm 0.01$ & $0.04 \pm 0.01$ & $0.04 \pm 0.01$ \\
\hline \multirow[t]{2}{*}{ mPAP } & GI & $21 \pm 5$ & $19 \pm 3$ & $20 \pm 5$ & $21 \pm 5$ & $20 \pm 6$ \\
\hline & GP & $22 \pm 6$ & $20 \pm 5$ & $21 \pm 3$ & $19 \pm 5$ & $22 \pm 5$ \\
\hline \multirow[t]{2}{*}{$\mathrm{mCPP}$} & GI & $9 \pm 4$ & $12 \pm 2$ & $12 \pm 3$ & $13 \pm 4$ & $11 \pm 3$ \\
\hline & GP & $14 \pm 5$ & $14 \pm 5$ & $15 \pm 3$ & $11 \pm 5$ & $14 \pm 6$ \\
\hline \multirow[t]{2}{*}{ TPR (dina $x$ seg/cm ${ }^{5}$ ) } & GI & $1620 \pm 291$ & $1435 \pm 320$ & $1480 \pm 286$ & $1507 \pm 286$ & $1550 \pm 373$ \\
\hline & GP & $1793 \pm 564$ & $1678 \pm 518$ & $1777 \pm 410$ & $1669 \pm 334$ & $1848 \pm 406$ \\
\hline \multirow{2}{*}{$\begin{array}{l}\text { TPRI } \\
\left(\text { dina } x \text { seg/cm } / \mathrm{cm}^{5} \text { ) }\right.\end{array}$} & GI & $2423 \pm 460$ & $2149 \pm 502$ & $2220 \pm 481^{\mathrm{A}}$ & $2260 \pm 483$ & $2317 \pm 576^{\mathrm{A}}$ \\
\hline & GP & $2898 \pm 988$ & $2719 \pm 921$ & $2872 \pm 761^{\text {B }}$ & $2699 \pm 661$ & $2987 \pm 760^{\mathrm{B}}$ \\
\hline \multirow[t]{2}{*}{ PVR (dina $\left.x \mathrm{seg} / \mathrm{cm}^{5}\right)$} & GI & $255.6 \pm 31$ & $149.6 \pm 43$ & $164.4 \pm 34$ & $152.7 \pm 73$ & $182.7 \pm 80$ \\
\hline & GP & $196.8 \pm 82$ & $142.3 \pm 69$ & $118.3 \pm 71$ & $196.9 \pm 138$ & $189.8 \pm 140$ \\
\hline \multirow{2}{*}{$\begin{array}{l}\text { PVRI } \\
\left(\text { dina } x \text { seg/cm } \mathrm{cm}^{5} \mathrm{~m}^{2}\right)\end{array}$} & GI & $382.2 \pm 53$ & $223.5 \pm 65$ & $245.8 \pm 52$ & $228.9 \pm 112$ & $274.2 \pm 124$ \\
\hline & GP & $319.6 \pm 148$ & $226.7 \pm 112$ & $188.9 \pm 115$ & $322.8 \pm 239$ & $310.2 \pm 242$ \\
\hline
\end{tabular}

$\mathrm{HR}$, heart rate; SAP, systolic arterial pressure; DAP, diastolic arterial pressure; MAP, mean arterial pressure; CVP, central venous pressure; $\mathrm{CO}$, cardiac output; $\mathrm{CI}$, cardiac index; SV, stroke volume; SI, stroke index; mPAP, mean pulmonary arterial pressure; mCPP, mean capillary pulmonary pressure; TPRI, total peripheral resistance index; TPR, total peripheral resistance; PVR, pulmonary vascular resistance; PVRI, pulmonary vascular resistance index. 
The results are given as mean \pm SD. Among groups: averages followed by different upper case letters in the column differ from each other $(\mathrm{P}<0.05)$. Between timing: averages followed by different lowercase letters in the row differ from each other $(\mathrm{P}<0.05)$.

\section{DISCUSSION}

The present study reports that propofol TIVA presents better hemodynamic stability during general anesthesia in piglets. According to the statistical method used in the study, there were only significant differences for SAP and TPRI variables. However, the values found for $\mathrm{HR}$, DAP, MAP, CVP, mPAP and mCPP were higher in GP. The values considered normal for awakened piglets for HR, DAP, MAP, CVP, mPAP and mCPP are $114-154 ; 91$ - 115; 67 $85 ; 5-13 ; 11-24 ; 5-15$, respectively (Hannon et al., 1990; Gianotti et al., 2010). Thus, in a clinical point of view, the group that received propofol presented averages closer to normality on most of the analyzed variables.

The oxygen $50 \%$-inspired fraction was chosen for the study because high $\mathrm{FIO}_{2}$ administration is related to the formation of atelectasis, interstitial alveolar edema, and pleural effusion areas (Crapo, 1986), which may be observed in patients under TIVA or inhalation, under spontaneous or controlled ventilation (Strandberg et al., 1986). Lopes et al. (2013) recommend that $100 \%$ and $21 \%$ inspired fractions of oxygen be avoided because they provided damage to the respiratory dynamics of dogs that were anesthetized with propofol under spontaneous ventilation.

Regarding hemodynamics at different concentrations of oxygen, Lodato (1989) reported that hyperoxia can cause hemodynamic changes such as reduction of HR, cardiac output, and increased blood pressure by systemic vasoconstriction. Nunes et al. (2008) evaluated the hemodynamics of dogs anesthetized with propofol under spontaneous ventilation, receiving a $\mathrm{FIO}_{2}$ of $1 ; 0.8 ; 0.6 ; 0.4$ and 0.21 , where they did not find significant differences between groups. However, in the work by Gianotti (2010), swine were anesthetized with propofol and remifentanil and then kept under controlled ventilation receiving different inspired fractions of oxygen. The author observed that the group submitted to $\mathrm{FIO}_{2}$ of 0.4 kept the ventilatory and hemodynamic variables more stable than in the groups that received inspired oxygen fractions of 0.8 and 0.6 . Thus, according to the studies of different inspired oxygen fractions, we chose a $\mathrm{FIO}_{2}$ of 0.5 , since it is an intermediate fraction, which could ensure a better stability of the evaluated variables in the study under discussion.

Physical restraint can be performed on small swine, but they stress easily, recommending, thus, the administration of a tranquilizer before preparing the animal for the methodology application (Flecknell, 2016). Unnecessary or excessive stress must be avoided, so different responses will not occur during the treatment (Pehböck et al., 2015). As a preanesthetic medication, azaperone was chosen, at $2 \mathrm{mg} / \mathrm{Kg}$. It is the choice for this specie, however, higher doses may result in hypotension, bradycardia and decreased cardiac output (Moon and Smith, 1996; Tranquilli and Grimm, 1996), which could negatively influence the evaluated variables in the study.

With respect to the studied variables, at GP, the means of systolic arterial pressure were higher than GI at all times, being closer to the values considered physiological for the species (Hannon et al., 1990). However, we could only observe significant differences at T30 and T60. Similar results were observed by Keegan and Greene (1993) when they anesthetized dogs using propofol or isoflurane. The authors reported higher means for systemic vascular resistance and systolic, mean, and diastolic arterial blood pressure for the propofol group. During TPR and TPRI values evaluation, we could observe that the group anesthetized by propofol remained higher than those with isoflurane, which can justify the higher means of SAP. In addition, inhaled anesthetics decrease the systemic vascular resistance and they may cause blood pressure to decrease (Steffey and Mama, 2007), a fact that was also verified in this study.

Regarding to TPRI, we observed lower averages at GI, with significant differences at T30 and T60, a fact that was also observed with the systolic arterial pressure findings at the same time. In this study, the TPR and TPRI mean values were higher at propofol, coinciding with data obtained by Keegan and Greene (1993), 
who found significantly higher values of TPR in dogs anesthetized with propofol when compared to isoflurane. Therefore, we can affirm that propofol maintains higher TPR and TPRI values and, consequently, higher blood pressure.

\section{CONCLUSION}

In conclusion, total intravenous anesthesia with propofol presented better results on hemodynamic variables in piglets receiving $\mathrm{FIO}_{2}$ of 0.5 under spontaneous ventilation.

\section{ACKNOWLEDGMENTS}

The authors would like to thank CAPES for the scholarship. The authors thank the Fundação de Amparo à Pesquisa do Estado de São Paulo FAPESP for financial support.

\section{REFERENCES}

AGUIAR, A.J.A.; LUNA, S.P.L.; OLIVA V.N.L.S. et al. Continuous infusion of propofol in dogs premedicated with methotrimeprazine. Vet. Anaesth. Analg., v.28, p.220-224, 2001.

BRUSSEL, T.; THEISSEN, J.L.; VIGFUSSON, G. et al. Hemodynamic and cardiodynamic effects of propofol and etomidate: negative inotropic properties of propofol. Anesth. Analg., v.69, p.35-40, 1989.

CRAPO, J.D. Morphologic changes in pulmonary oxygen toxicity. Ann. Rev. Physiol., v.48, p.721-731, 1986.

EGGER II, E.I. Isoflurane: a review. Anesthesiology, v.55, p.559-576, 1981.

FLECKNELL, P. Anaesthesia of common laboratory species: special considerations. In: FLECKNELL, P (Ed.). Laboratory animal anaesthesia. 4.ed. Oxford: Elsevier, 2016. p.193256.

GIANOTTI, G.C. Dinâmica cardiorrespiratória de suínos sedados e submetidos a diferentes frações inspiradas de oxigênio em ventilação mecânica volume versus pressão controlada. 2010. 72f. Dissertação (Mestrado em Medicina Veterinária) - Faculdade Federal do Rio Grande do Sul, Faculdade de Veterinária, Porto Alegre, RS.
GIANOTTI, G.C.; BEHEREGARAY, W.K.; BIANCHI, S.P. et al. Suíno como modelo experimental na pesquisa biomédica: valores fisiológicos normais. Acta Sci. Vet., v.38, p.133137,2010

GLOWASKI, M.M.; WETMORE, L.A. Propofol: application in veterinary sedation and anesthesia. Clin. Tech. Small Anim. Pract., v.14, p.1-9, 1999.

GOODCHILD, C.S.; SERRAO, J.M. Cardiovascular effects of propofol in the anaesthetized dog. Br. J. Anaesth., v.63, p.87-92, 1989.

GUERRERO, P.N.H.; NUNES, N. Monitoramento do índice bispectral em cães. Semin. Ciênc Agrár v.24, p.163-170, 2003.

HANNON, P.J.; BOSSONE, C.A.; WADE, C.E. Normal physiological values for concious pigs used in biomedical research. Lab. Anim. Sci, v.40, p.293-298, 1990.

KEEGAN, R.D.; GREENE, S.A. Cardiovascular effects of a continuous two hour propofol infusion in dogs comparison with isoflurane anaesthesia. Vet. Surg., v.22, p.537-543, 1993.

LODATO, R.F. Decreased oxygen consumption and cardiac output during normobaric hyperoxia in concious dogs. J. Appl. Physiol., v.67, p.1551$1559,1989$.

LOPES, P.C.F.; NUNES, N.; SOUSA, M.G. et al. The effects of different inspired oxygen fractions on gas exchange and Tei-index of myocardial performance in propofol-anesthetized dogs. Vet. Anaesth. Analg., v.40, p.573-583, 2013.

MASSONE, F.; CORTOPASSI, S. R. G. Anestesia Intravenosa. In: FANTONI, D.T; CORTOPASSI, S. R. G. (Ed). Anestesia em cães e gatos. 2. ed. São Paulo: Roca, 2010. p. 228236.

MOON, P.F.; SMITH, L.J. General anesthetic techniques in swine. Vet. Clin. N. Am. Food. Anim. Pract., v.12, p.663-691, 1996.

MUSK, G.C.; PANG, D.S.J.; BETHS, T. et al. Target-controlled infusion of propofol in dogs evaluation of four targets for induction of anaesthesia. Vet. Rec., v.157, p.766-770, 2005. 
NUNES, N. Monitoração da anestesia. In: FANTONI, D.T.; CORTOPASSI, S.R.G. (Ed). Anestesia em cães e gatos. 2.ed. São Paulo: Roca, 2010. p.83-101.

NUNES, N.; LOPES, P.C.F.; SANTOS, P.S.P. et al. Hemodinâmica de diferentes frações inspiradas de oxigênio em cães submetidos à infusão contínua de propofol sob ventilação espontânea. Ciênc Rural, v.38, p.729-735, 2008.

OGILVIE, G.K. Chemotherapy. In: WITHROW, S.J.; MACEWEN, E.G. (Eds.). Small animal clinical oncology. 2.ed. Philadelphia: W.B. Saunders. 1996. p.75.

PAGEL, P.S.; KAMPINE, J.P.; SCHMELING, W.T. et al. Comparison of the systemic and coronary hemodynamic actions of desflurane, isoflurane, halothane, and enflurane in the chronically instrumented dog. Anesthesiology, v.74, p.539-551, 1991.

PEHBÖCK, D.; DIETRICH, H.; KLIMA, G. et al. Anesthesia in swine: optimizing a laboratory model to optimize translational research. Anaesthesist, v.64, p.65-70, 2015.

PINSKY, M.R.; PAYEN, D. Functional hemodynamic monitoring. Crit. Care, v.9, p.566$572,2005$.
SANTOS, P.S.P.; NUNES, N.; SOUZA, A.P. et al. Hemodynamic effects of butorphanol in desflurane-anesthetized dogs. Vet. Anaesth. Analg., v.38, p.467-474, 2011.

SHAFER, S.L. Advances in propofol pharmacokinetic and pharmacodynamics. J. Clin. Anesth., v.1, p.14-21, 1993.

STEFFEY, E.P.; MAMA, K.R. Inhalation Anesthetics. In: THURMON, J.C.; TRANQUILLI, W.J.; BENSON, G.J. (Eds.). Lumb \& Jones' veterinary anesthesia and analgesia. 4.ed. Oxford: Blackwell Publishing, 2007, p.355-393.

STRANDBERG, A.; TOKICS, L.; BRISMAR, B. et al. Atelectasis during anaesthesia and in the postoperative period. Acta Anaesthesiol. Scand., v.30, p.156-158, 1986.

TRANQUILLI, W.J.; GRIMM, K.A. Pharmacology of drugs used for anesthesia and sedation. Vet. Clin. N. Am. Food Anim. Pract., v.12, p.501-529, 1996.

WHITWAM, J. G.; GALLETLY, D.C.; MA, D. et al. The effects of propofol on heart rate arterial pressure and $\mathrm{A}$ and Csomatosympathetic reflexes in anesthetized dogs. Eur. J. Anaesthesiol., v.17, p.57-63, 2000 . 